\title{
INTEGRATING ACTIVE LEARNING IN A COLLEGE SPEAKING CLASS
}

\author{
Pryla Rochmahwati \\ STAIN Ponorogo \\ rpryla@yahoo.com / rpryla@gmail.com
}

\begin{abstract}
Active learning strategies provide a wide variety of activities which can be integrated in a College EFL Class especially on Speaking 1 Course at Ponorogo Islamic State College. They provide many benefits, such as giving the students' chances to apply various ways in order to comprehend the material. Also, they emphasize the significance of the learner's involvement in the learning process. Active Learning strategies are considered appropriate to give students the same amount of chance in practicing their speaking skill and to pay attention in creating a learning situation. Some active learning strategies including the advantages and their application procedures are intended to help learners achieve the objective of Speaking1 course are presented in the article. Lecturers may, however, find that some just do not fit their style of teaching or that others would work well in their speaking class or with modifications. On the other hand, there are some obstacles that occur during the-implementation of active learning, namely disinterested students and time pressures.
\end{abstract}

\section{Keywords: active learning, speaking}

In learning a foreign language, one is considered to have mastered the target language when $\mathrm{s} /$ he is able to utilize it in speaking. Nunan (1991: 39) states that tomost people, mastering the art of speaking is the most important aspect of learning a foreign language and success is measured in terms of the ability to carry out a conversation in the language. Richards and Renandya (2002: 201) also say that a large percentage of the world's language learners study English in order to develop proficiency in speaking.

A common problem that occurs in a speaking class is that instructors frequently feel it difficult to involve students in the speaking activities. In fact, English instructors should work hard to attract the students to speak a lot in the class. One of the major obstacles learners have to overcome in learning to speak is the anxiety generated over the risks of blurting things out that are wrong, stupid, or incomprehensible (Brown, 2001: 269). Some views of speaking problems were supported by the claim that some EFL learners are reluctant to speak because of many factors, such as inadequate vocabulary and control of grammar, lack of fluency, encouragement, and the students' nervousness (Nation \& Newton, 2009:112). These problems are still frequently experienced by instructors and become a challenge for them in teaching speaking.

Active learning, therefore, is alleged to help in solving this problem. It emphasizes the significance of the learner's involvement in the learning process and may involve independent inquiry, collaborative learning, self-awareness of the individual's own learning process, and purposeful adaptation 
of new knowledge to the learner's prior experience, current interests and future goals (Slavin, 1997). Active learning is, in short, any learning activity engaged in by students in a classroom other than listening passively to the lecturer.

Active learning includes a wide range of activities that share the common element of involving students in doing things and thinking about the things they are doing (Bonwell \& Eison 1991). It implies that active learning turn the focus of instruction from what should you (the teacher) deliver to students to what do you want students to be able to do with material. Consequently, when students recognize that your class involves active learning, they will also recognize that they must be active if they want to succeed in the speaking class.

In this paper, the nature of speaking and idea of successful EFL Speaking activities is first highlighted. Then, the concepts of active learning is elaborated and illustrated, where appropriate, with examples from Speaking 1 course. In addition, The writer hopes that my her experiences will be encouraging to other lecturers who may be considering active learning strategies for their own classes.

\section{The Nature of Speaking}

Speaking is an interactive process of constructing meaning that involves producing, receiving, and processing information (Burns and Joyce, 1997: 2). In this sense, the ability to speak another language is not that simple; it needs to know the nature and characteristic of spoken language, which requires very complex skills and knowledge of its language. Therefore, students need to gain awareness of practicing aspect of linguistics knowledge, developing production skills, and raising some socio-linguistic or pragmatic points (Hughes, $R, 2002: 6)$.

\section{Successful EFL Speaking Activities}

According to Ur (1996:120), there are four characteristics of successful speaking activi- ties. First, learners are talking a lot during speaking class. It implies that the lecturers are required to provide the activities in which the students inhabit the most time to talk. The second, the participants have the same chances to speak. It infers that the classroom activities should not be dominated by active students. The third, motivation is high. It means the activities can make the students eager to speak because they are interested in the provided topic. The fourth, the level of language is acceptable. It means that the learners can express in relevant, acceptable and comprehensible the words to each other when they assign to practice speaking.

Harmer (1998: 87) gives some good ideas for speaking activities that can arouse the students to practice their English. He explains three activities for speaking activities namely, (1) Rehearsal - the students are assigned to practice speaking outside the classroom and to take part in a role play such a real-life event in the classroom. (2) Feedback - the lecturers can see how well the students are doing the activities and what language problems they are having. (3) Engagement - it means that good speaking activities should be highly motivating in order to participate actively during speaking class.

To sum up, it is important to give students the same amount of chance in exercising their students' speaking skill and to pay attention in creating a learning situation by various learning activities or teaching techniques.

What is Active Learning?

Over the past decade, active learning approach has been applied at more and more universities and is being proved very effective in improving student learning. Active learning is, in short, any learning activity engaged in by students in a classroom other than receiving material passively from the lecturer.

Active learning involves providing opportunities for students to meaningfully talk and listen, write, read, and reflect on the content, ideas, issues, and concerns of an academic 
subject (Meyers \& Jones, 1993: 6). It infers that active learning gives the students chances to apply various ways in order to comprehend the material. Students can work individually or in groups, and strategies can take as little as two minutes or as long as an entire session. They then asserted that active learning derives from two basic assumptions, namely (1) learning is by its very nature an active process and (2) that different people learn in different ways. It shows that learning is searching knowledge actively by using various ways.

Basically, the background of the active learning concept is derived from Confucius' aphorism:

I hear and I forget.

I see and I remember.

I do and I understand.

Unfortunately, in most classrooms, we are limited to the very senses Confucius claims to be ineffective pathways for understanding. When used in isolation, hearing or seeing does not make for the kind of learning we wish to create in the classroom. Then, Silberman (1996 in Sarjuliet al., 2007) modified the notion become

"what I hear, I forget; what I see, I remember a little; what I hear, see and ask questions about or discuss with someone else, I begin to understand; what I hear, see, discuss, and do, I acquire knowledge and skill; what I teach to another, I master"

Active learning shifts the focus from the teacher's delivery of material to the students'. Through active learning techniques and modeling by the teacher, students discard the traditional role as passive receivers and acquire and practice how to apprehend knowledge and skills and use them meaningfully. The active learning offers many variations of strategies (Silberman in Sarjuli et all, 2007), they are in the following:

a. True or False? - Distribute index cards (one to each student) on which is written a statement. Half of the cards will contain statements that are true, half false. Students decide if theirs is one of the true statements or not, using whatever means they desire.

b. Concept Mapping - Students write keywords onto sticky notes and then organize them into a flowchart. Could be less structured: students simply draw the connections they make between concepts.

c. Student Storytelling - Students are given assignments that make use of a given concept in relation to something that seems personally relevant (such as requiring the topic to be someone in their family).

d. Chain Notes - Instructor pre-distributes index cards and passes around an envelope, on which is written a question relating to the learning environment (i.e., are the group discussions useful?) Students write a very brief answer, drop in their own card, and pass the envelope to the next student.

e. Think-Pair-Share - Students share and compare possible answers to a question with a partner before addressing the larger class.

f. Jigsaw (Group Experts) - Give each group a different topic. Re-mix groups with one planted "expert" on each topic, who now has to teach his new group.

g. Classroom Assessment Quality Circles - A small group of students forms a "committee" on the quality of teaching and learning, which meets regularly and includes the instructor.

h. Hollywood Squares - Choose students to sit as "celebrities" at the front of the class. Variation: allow the celebrities to use books and notes in deciding how to help the contestants.

i. Student Questions (Index Cards) - At the start of the semester, pass out index cards and ask each student to write a question about the class and your expectations. The cards rotate through the room, with each student adding a check-mark if they agree this question is important for them. The teacher learns what the class is most anxious about. 
j. Role-Playing - Assign roles for a concept, students research their parts at home, and they act it out in class. Observers critique and ask questions.

k. Role Reversal - Teacher role-plays as the student, asking questions about the content. The students are collectively the teacher, and must answer the questions. Works well as test review/prep.

1. Press Conference(Guest Speaker) - Invite a guest speaker and run the class like a press conference, with a few prepared remarks and then fielding questions from the audience.

m.Fishbowl - A student unpacks her ideas and thoughts on a topic in front of others, who take notes and then write a response. Avoid asking questions.

\section{Sampling of Active Learning Strategies in Speaking 1 Course}

When students learn actively, they keep in mind more material for a longer time and are able to apply that material in a broader range of contexts. All techniques incorporated to active learning model are intended to help learners make relevant connections among course materials; transforming course materials from impervious ideas into something that can integrate into their own long-term memory. The activities that follow are intended to help learners achieve the objective of speaking 1 course. Instructors or lecturers may, however, find that some just do not fit their style of teaching or that others would work well in their classroom or with modifications.

\section{Really Getting Acquainted}

This strategy gives chances to the students to get to know each other deeply (Silberman in Sarjuliet all, 2007: 59). This strategy is appropriate to be applied for the first meeting when the topic is "Introduction". The procedures are in the following:

a. Present the topic and the expression used in "Introduction" b. Distribute worksheet / guidelines consisting of the point about personal identity.

c. Divide the class into several groups

d. Assign the students to have interview the member of the group

e. Ask the students to introduce the member of the group in front of the class.

\section{Group Information Exchange}

Group work has long been accepted as an effective learning strategy because it provides opportunities for students to negotiate meaning and manipulate ideas with others and reflect upon their learning (Fraser \& Deane,1997 in Burdett, 2003: 177).These activities provide the students a media to exchange their thoughts and establish a good communication between or among the students. In this time, the topic is about "Schedule and Routine", this strategy can be applied in the following:

a. Divide the class into several groups

b. Assign the students to exchange information about their activity on the weekend in their group.

c. Move around the class to facilitate the students

d. Give reinforcement

\section{Information Search}

This simple strategy stimulates the students curiosity about the discussed topic (Silberman in Sarjuli et al, 2007: 152). In talking about "Unusual Hobbies and Interest", the students are encouraged to talk about their hobbies and interest. Also, they are eager to know their friends'. The procedures of the strategy are in the following:

a. Stimulate students' background knowledge about their hobbies and interest by giving questions e.gwhat's your hobby? Why do you like it? How often do you do it in a week? Etc.

b. Divide the class into several groups.

c. Distribute a worksheet containing a set of questions about "Unusual Hobbies and Interest" 
d. Assign each group to browse in internet or read the book, magazine or newspaper in order to find the answer.

e. Discuss the answers in a group

f. Move around the class to facilitate the group in order not to have the same information

g. Assign each group to present

h. Give clarification and reinforcement.

4. I Am The.....

The strategy keeps the students to practice speaking through describing or acting out to be someone else (Silberman in Sarjuli et al, 2007: 230). The writer applied the strategy when the topic was about "Describing person, thing and place". In order to help the students to have idea to initiate speaking, the lecturer can use pictures as media. Pictures create situation which interests the students. According to Wright (1992:17), pictures can motivate the students to participate in the language activities and contribute to the context in which the language is used. The procedures are in the following:

a. Present the topic and the expression used in "Describing person, thing and place"

b. Divide the class into several groups

c. Distribute pictures - famous person, profession, animals, things, buildings, public places etc. (each group accepts different pictures)

d. Assign the group to describe the picture to be presented in front of the class without mentioning what the picture is and other group guess what it is

e. Give clarification and reinforcement.

\section{Firing Line}

The activities in firing line strategy provide the students opportunity to respond the questions / statement / request quickly. When the topic is about "Past Event", this strategy considered appropriate to be employed. The writer combined this strategy with storytelling. Storytelling is a good way to combine instruction and entertainment and it can stimulate imagination (Tompkins and Hoskisson (1995:129). The strategy can be employed in the following:

a. Divide the class into several groups.

b. Play a video related to past event - Fairy Tales such as Snow White and Seven Dwarfs, Cinderella. Fables such as Hare and Tortoise.

c. Assign the students to discuss the story in group

d. Ask the 5 or 6 students randomly to stand in line in front of the class to tell the story in turn. $\left(1^{\text {st }}\right.$ student start the story in one sentence, the next sentence continued by $2^{\text {nd }}$ student, $3^{\text {rd }}$ student keep on the next sentence,

till the story come to an end)

e. Give comment and reinforcement.

\section{Role Play}

Blatner (2002:1) says that Role Play is a method for exploring the issues involved in complex social situations. In Role Play the participants are assigned roles which they act out in a given scenario. The activities are presented below:

a. Explain the topic (How To Get There) and the expression used.

b. Divide the class into several groups.

c. Distribute situation cards and map.

d. Assign the student to play role based on the cards and map.

e. Give comments and reinforcement

\section{Hollywood Squares Review}

Hollywood Squares is an American panel game show in which two contestants play tic-tac-toe to win cash and prizes. The "board" for the game is a $3 \times 3$ vertical stack of open-faced cubes, each occupied by a celebrity seated at a desk and facing the contestants. The stars are asked questions and the contestants judge the veracity of their answers in order to win the game (http:/ / en.wikipedia.org/wiki/Hollywood_Squares). Inspiring by the game, Sil- 
berman (year?) modified it into the teaching strategy.

When the topic is about "Asking for and Giving Opinion, the lecturer applied this strategy. Here, the class is set up:

a. Review the expression of "Asking for and Giving Opinion"

b. Assign the students to make question using the expression of "Asking for Opinion" in the piece of paper and put it on the secret box.

c. Invite the students in turn to come forward to take the question and answer spontaneously

d. Give score in each performance

e. Clarify and announce the winner of the game.

\section{Poster Session}

This strategy creates good atmosphere in teaching and learning process in which the students feel free to express the idea based on the selected poster. Poster can be defined as a large printed picture, notice, or advertisement displayed in a public place (http://oxforddictionaries. com/definition/english/poster). Typically posters include both textual and graphic elements, although a poster may be either wholly graphical or wholly text. Posters are designed to be both eye-catching and informative. Therefore, through its interactive and informative design, poster considered good media to stimulate the students to talk about.

When the topic is about "Hopes and Dream", the students hopefully express their imaginative idea through posters. On the other hand, during the implementation of the strategy, other participants will be invited to give comments, questions or even exchanged idea. The procedures are in the following:

a. Divide class into 6 or 8 groups

b. Assign each group to find or make poster related to their hopes and dream

c. Assign each group to present in front of the class, while other participants give feedback

d. Provide group assessment checklist to evaluate their participation during the class session.

e. Give clarification and reinforcement

\section{Simulation}

A simulation can be defined as an activity in which a person is placed into a scenario or situation and is directly responsible for the changes that occur as a result of their decisions. There is little consensus on the terms used in the role playing and simulation. Simulations simulate real life situations, while in role playing; the participant is representing and experiencing some character type known in everyday life (Scarcella and Oxford, 1992).

In this time, the topic is about "Food and Drink". The students focused their attention on how to make something. Therefore, the appropriate strategy to teach procedure text is simulation. The steps are in the following:

a. Divide the class into several groups and assign each group to select one of food and drink, prepare ingredient and tools, and discuss how to make it in the previous meeting.

b. Provide the students with vocabulary items for making something e.g imperative.

c. Assign each group to have simulation in front of the class

d. Give chances for other groups to give comments

e. Give clarification and Reinforcement.

\section{In the Nerws}

This strategy attracts the students' attention to involve actively for finding the news / topic even before they come to the class (Silberman in Sarjuliet all, 2007: 178). The students are assigned to select the topic accordance to their interest. On the other hand, the students are supported to find the current issues. Hopefully, they can 
participate actively during the speaking session dealing with the topic "Reporting Current Event".

The strategy can be conducted in the following procedures:

a. Come up with the explanation on the expression of Reporting. An event.

b. Divide the class into several groups

c. Assign the students to browse the information in internet and select the current event to be reported.

d. Report the information in front of the class in turn (each member of the group is required to speak / give additional information related to the event.

e. Give clarification and reinforcement.

11. Jigsaw

Jigsaw is a teaching technique used in small group, invented 1971 by a graduate professor named Elliot Aronson. In team Jigsaw, students form "temporary mastery teams" or "expert groups" with different learning assignments to master. Students then return to their original or "home" teams and share new knowledge with teammates.

When the topic is talking about "Entertainment", this strategy is considered appropriate. The jigsaw classroom is very simple to use. These are the steps to be followed:

a. Divide students into 5- or 6-person jigsaw groups.

b. Appoint one student from each group as the leader.

c. Divide the day's lesson into 5-6 segments. For example, TV program in Indonesia - (1) News, (2) Sinetron (electronic Cinema), (3) Film, (4) Infotainment, (4) Kid programs, (5) Talk Show, (6) Music etc.

d. Assign each student to learn one segment, making sure students have direct access only to their own segment.

e. Give students time to read over their segment at least twice and become familiar with it. There is no need for them to memorize it. f. Form temporary "expert groups" by having one student from each jigsaw group join other students assigned to the same segment. Give students in these expert groups time to discuss the main points of their segment and to rehearse the presentations they will make to their jigsaw group.

g. Bring the students back into their jigsaw groups.

h. Ask each student to present her or his segment to the group. Encourage others in the group to ask questions for clarification.

i. Give a quiz on the material so that students quickly come to realize that these sessions are not just fun and games but really worth learning.

\section{Interactive Drama}

Cheng (2007:1) states that Interactive dramas are a language learning activity in which each student in the class takes a distinctive role with specific goals and then interacts with other students in the class to build partnership and achieve corporate goals. It means that an interactive drama is an event in which the director and players work together to create a role. Alptekin (2002:58) points out that Interactive drama provides an alternative way to expose students to the culture that native English speakers have as part of their background knowledge. They also provide students with an activity for practicing the appropriate use of language - in this case "Emotion and Feeling".

The activity can be conducted in the following procedures:

a. Divide the class into several groups and assign them to discuss about their emotion and feeling in free cases.

b. Assign them to make scenario in which each student requires to talk actively during their performance's time.

c. Explain the scoring criteria.

d. Assign each group to perform in front of 
class while the audiences assess them.

e. Give reward for the best performance

f. Give clarification and reinforcement.

Problems on Its Implementation

Using active learning sometimes face persistent problems. Foremost among the obstacles perceived is that it takes too much time to prepare (particularly when an instructor has taught the course before and already has lectures prepared). For instance, the strategy under "Interactive Drama" and "Simulation", require an extended time to prepare the scenario, and the tools for performance. However, once the instructors have developed active-learning strategies for a given course, they can be used each time the course is taught (and the strategies can be adapted for other courses as well). Also, some activelearning strategies require little or no added preparation time.

The next obstacle concerns with the fear of "losing control" of the class students will react negatively. During the implementation of active learning especially when they were assigned to work in group, many of the group

\section{REFERENCES}

Alptekin, C. (2002). Towards Intercultural Communicative Competence in ELT. ELTJournal, 56(1), 57-64.

Blatner, A. (2002). Role Playing in Education. Retrieved October 22 ${ }^{\text {nd }}, 2007$ from:

(http://www.blatner.com/adam/papers. htm)

Bonwell, C., \&Eison, J. (1991). Active learning: Creating Excitement in The Classroom (ASHE-ERIC Higher Education Report No. 1). Washington, DC: George Washington University. Abstract online at http://www.ed.gov/databases /ERIC_Digests/ed340272.html

Brown H.D. (2001). Teaching by Principle: An Interactive Approach to Language Pedagogy. New York: Longman.

Burdett, J. (2003). Making Groups Work: Uni- teams in my class are not working well-their assignments are superficial and incomplete and some team members keep complaining to me about others not participating. Teams working together on doing assignments may always rely on one or two members to handle presentation or report the result of discussion. The others may then be reluctant to speak when they assign to speak individually.

\section{CONCLUSION}

Active Learning provides a wide variety of strategies which can be used to complement rather than replace lectures. Active learning strategies are becoming more widely used in college classrooms as lecturers discover their many benefits. In order to achieve the objective of Speaking 1 course, active learning strategies is considered suitable to be conducted. Examples of how to incorporate active learning in speaking course are explained in this article. Nevertheless, we cannot avoid the obstacles when implementing active learning strategies in terms of disinterested students and time pressures.

versity Students'Perceptions.International Education Journal Vol 4, No 3, 2003.http://ehlt.flinders.edu.au here/ education/iej/articles/v4n3/Burdett/paper.pdf

Burns, A., \& Joyce, H. (1997). Focus on Speaking. Sydney: Macquarie University Press.

Cheng, Michael. (2007). Student Perceptions of Interactive Drama Activities. Journal ofInteractive Drama, Vol. 2.3, November, 2007

Ferguson. (2004). Communication Skill. New York: Ferguson

Harmer, J. (1998). How to Teach English. Essex: Addison Wesley Longman

Hughes, R. (2002). Teaching and Researching Speaking. London: Pearson Educa- 
tion

Meyers, C. \& Jones, T.M. (1993).Promoting Active Learning Strategies for The College Classroom. London: John Wiley\& Sons, Inc.

Nation, I. \& Newton, J. (2009).Teaching ESL/ EFL Listening and Speaking. New York: Routledge.

Nunan, (1991).Language Teaching Methodology: A Textbook for Instructors. English Language Teaching. New York: Prentice Hall.

Richards, J. C. and Renandya, W. A. (2002). Methodology in Language Teaching: An Anthology of Current Practice. Cambridge: Cambridge University Press.

Scarcella, R. \& Oxford, R. L. (1992).The Tapestry of Language Learning. Boston:Heinle and Heinle.

Sarjuli. (2007). Active Learning: 101 Strategi Pembelajaran Aktif. Yogjakarta: PustakaInsanMadani.

Slavin, Robert. E. (1997). “Cooperative Learning Among Students." In Active Learning for Students and Teachers: Reports from Eight Countries, ed. David Stern and Günter L. Huber. New York: Peter Lang.

Tompkins, G.E., \& Hoskisson, K. (1995). Language Arts: Content and Teaching Strategies. Ohio, USA: Prentice-Hall.

Ur, P. (1996). A Course in Language Teaching. Cambridge: Cambridge University Press.

Wright, A. (1992). Pictures for Language Learning. (5 $\left.5^{\text {th }} E d\right)$. New York: Cambridge University Press. 
